\title{
The Effect of Transformational Leadership and Individual Entrepreneurial Orientation on Innovation Work Behavior through Knowledge Sharing in PT. Arga Bangun Bangsa
}

\author{
Hilwan Khulaifi ${ }^{1}$ \\ Master of Management, Mercu Buana University \\ Jakarta, Indonesia
}

\begin{abstract}
This study aims to find out and explain the effects of transformational leadership and individual entrepreneurial orientation (IEO) on innovation work behavior (IWB) through knowledge sharing. Respondents 115 employees. Data collection is done through interviews and questionnaires. Data were analyzed using path analysis (SmartPls 3.0 software) and correlation dimensions between dimensions (SmartPls 3.0 software). The results of the study show that: (1) transformational leadership and IEO partially influence knowledge sharing; (2) transformational leadership, IEO, and knowledge sharing simultaneously affect IWB; (3) knowledge sharing has no effect on IWB; (4) knowledge sharing does not mediate the effects of transformational leadership and IEO on IWB. Based on the correlation matrix analysis between dimensions, to improve transformational leadership, which has a positive correlation with knowledge sharing, it is advisable to maintain and improve the dimensions of individualized consideration, and for IWB, namely motivational inspiration. To improve IEO, which has a positive correlation with knowledge sharing and IWB, it is advisable to maintain and improve the dimensions of proactive, and for IWB, namely innovative.
\end{abstract}

Keywords:- Innovation Work Behavior, Transformational Leadership, Individual Entrepreneurial Orientation, and Knowledge Sharing.

\section{INTRODUCTION}

The Global Innovation Index 2019 (GII) recently ranked Indonesia 85th (out of 142 countries). On the ASEAN scale, Indonesia is still lagging behind by Singapore (8), Malaysia (35), Vietnam (42), Thailand (43), Philippines (54), and Brunei Darussalam (71). GII is an annual ranking of a country based on a country's capacity and success in terms of innovation. The GII report (2019) reveals the role of innovative behavioral activities in overcoming the economy one by one.

According to a World Bank survey on the Knowledge Economy Index That is why the focus of this research is on innovation, in particular this focus on innovative behavior in the corporate sector in the field of Knowledge Intensive

\author{
Charles Bohlen Purba ${ }^{2}$ \\ Lecturer of Postgraduate, Mercu Buana University \\ Jakarta, Indonesia
}

Business Services (KIBS). One of the consulting service companies in Indonesia that is included in the KIBS classification is PT. Arga Bangun Bangsa. PT Arga Bangun Bangsa is part of the ESQ Group, which was founded in 2000 and is one of the leading consulting companies in Indonesia that provides services such as research \& development, character building, organizational culture transformation, leadership development, strategic plan formation services, and business innovation services.

Based on Organizational Culture Health Index (OCHI) culture survey data, where the survey aims to see the current and expected value / behavior gaps in a company to see the mapping of an organization's cultural values. The survey results found that the organizational values / behaviors most expected by the employees of PT Arga Bangun Bangsa are innovation, only after that open communication, continuous improvement, professionalism, personal development, organizational growth, leading by example, cooperation, integrity, and professional development.

Transformational Leadership at PT Arga Bangun Bangsa. From the interviews it was found that transformational leadership is in the low position at $38 \%$. Similarly, Top Leaders (31\%) and Middle Leaders (44\%) are in the low category at PT Arga Bangun Bangsa. From interviews on the orientation of individual entrepreneurs owned by PT Arga Bangun Bangsa employees, it was found that they were in the low category (46\%) (Table 1.5). Most employees do have a good decision-making attitude, but are less innovative and proactive about all the changes that occur.

Based on the results of the pre-survey regarding knowledge sharing with 18 employees, it can be seen that knowledge sharing falls into the low category of $31 \%$.

In these results it was found that the behavior of individuals or groups is fairly low in terms of communicating intellectual knowledge / models possessed to others. In addition, the low behavior of mutual consultation between individuals and groups in order to gain knowledge. 


\section{LITERATURE REVIEW}

\section{$>$ Innovative Work Behavior}

Innovative work behavior is a series of work activities that are gradually carried out with the aim to develop and improve effective work behavior (De Jong and Hartog, 2010; 5). According to Janssen (in Setyowati \& Etikariena, $2019 ; 116)$, there are three stages in the formation of innovative work behavior, namely the idea of generalization, the idea of promoting, and the idea of realization. De Jong \& Hartog $(2010 ; 24)$ put forward four dimensions of innovative behavior as follows: Opportunity Exploration, opportunity exploration is an innovative process determined by opportunity or opportunity. Opportunities will trigger individuals to look for ways to improve service, delivery processes, or try to think of a new alternative regarding work processes, products or services. The second, Idea Generation, idea generation is the management of information and concepts that have been there to improve performance. Individuals who are high in this level will be able to see the solution of a problem with a different way of thinking.

Championing, involving behavior to find support and build coalitions, such as inviting and influencing employees or management, and negotiating about a solution. And the last, Implementation, individuals not only think about creative ideas about a thing but also apply those ideas into concrete actions, individual creative ideas are protected by copyright law.

\section{Transformational Leadership}

In transformational leadership, employees can easily share knowledge between members in organizations so that organizations with transformational leaders tend to have high intellectual and interpersonal closeness so that motivation can increase (Paracha, Qamar, Mirza, Hassan, \& Waqas, 2012; 57).

Bass in Yukl (2010; 305) adds the transformational leadership component to four. The first is Idealized Influence, it means the behavior of the leader who makes his followers admire, respect, and at the same time trust him. The second, Inspiring Motivation, is a leader who is able to actualize high expectations of the achievements of subordinates, demonstrates his commitment to all organizational goals, and is able to arouse enthusiasm in the organization through growing enthusiasm and optimism.

The third, Intellectual Stimulation, is a leader who is able to foster new ideas, provide creative solutions to the problems faced by subordinates, and provide motivation to subordinates to look for new approaches in carrying out organizational tasks. The fourth is Individual Considerations, are leaders who want to listen attentively to subordinate input and specifically want to pay attention to the needs of subordinates and specifically want to pay attention to the needs of subordinates for career development.

\section{$>$ Individual Entrepreneurial Orientation}

According to Saragih $(2017 ; 26)$, entrepreneurship is creative and innovative, keen to see opportunities and always open to every positive input and change that is able to bring business to continue to grow. Meanwhile according to Listyawati (2017: 58) defines that entrepreneurship is a human activity by exerting the energy of the mind or body to achieve and create a job that can realize noble beings. Individual entrepreneurial orientation is a float of Langkamp Bolton and Lane (2012: 221) which divides the dimensions into three, as follows:

- Innovativeness, defined as an individual's inclination towards creativity and experimentation through the introduction of new products and services and technological leadership through research and development in new processes.

- Proactiveness, is an individual perspective to look for opportunities and forward-looking, characterized by new products and services in front of competition and acting to anticipate future demand.

- Risk-taking is a bold act by venturing into the unknown, borrowing heavily and / or doing significant resources to wander in an uncertain environment.

\section{$>$ Knowledge Sharing}

Knowledge sharing is an exchange of information between individuals and between teams, organizational units, and organizations, both focused and unrelated to something that does not have to eliminate the previous goal or exchange of information between two individuals where one individual communicates his knowledge and the individual then understands what is conveyed (Jaberi , 2016: 43).

The process of sharing knowledge can be understood as a process where employees exchange knowledge and jointly produce new knowledge (Van den Hoof and Van Weenen in Islamy and Mubarok, 2019; 157). Knowledge sharing also mentioned can be assessed based on two dimensions of the process, which consists of:

- Knowledge Donating, is the behavior of individuals or groups to communicate knowledge / intellectual models that are owned to others.

- Collecting Knowledge, the behavior of individuals or groups to consult with each other in order to obtain knowledge / intellectual models that are owned and communicated by others. Knowledge collecting is also done to encourage others to do knowledge sharing.

\section{CONCEPTUAL FRAMEWORK}

The framework of thought explains the relationship of quality and influence between the variables studied. The form of the framework of thinking in this study outlined, that innovative work behavior is influenced by factors of transformational leadership, individual entrepreneurial orientation, and knowledge sharing. 


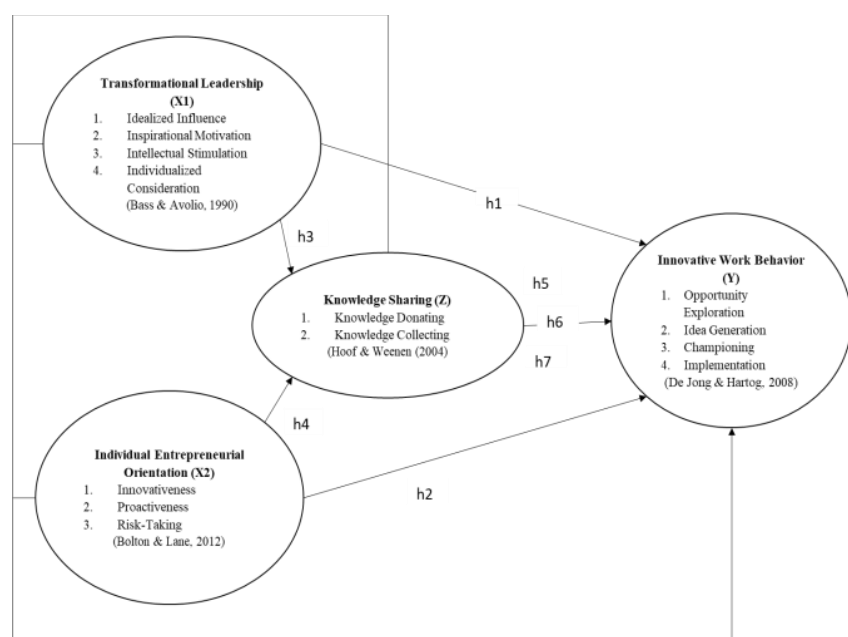

Fig 1:- Conceptual Framework

\section{$>$ Hypothesis}

Based on those problem, the study of the theory and conceptual framework that has been revealed, therefore the authors form the formulate as the hypothesis as it follows: H1: There is a significant influence on transformational leadership on innovative work behavior at PT Arga Bangun Bangsa. H2: There is a significant influence of individual entrepreneurial orientation on innovative work behavior at PT Arga Bangun Bangsa. H3: There is a significant influence on transformational leadership on knowledge sharing at PT Arga Bangun Bangsa. H4: There is a significant influence of individual entrepreneurial orientation on knowledge sharing at PT Arga Bangun Bangsa. H5: There is a significant influence of knowledge sharing on innovative work behavior at PT Arga Bangun Bangsa. H6: There is a significant influence on transformational leadership on innovative work behavior through knowledge sharing at PT Arga Bangun Bangsa. H7: There is a significant influence of individual entrepreneurial orientation on innovative work behavior through knowledge sharing at PT Arga Bangun Bangsa.

\section{RESEARCH METHODOLOGY}

\section{$>$ Samples and Populations}

The population in this study consisted of all employees of PT Arga Bangun Bangsa, amounting to 162 people. While the sample taken is the census method in which the entire population is sampled (probability saturation sampling), then the number of samples in this study were 115 respondents. The sampling technique that will be used is non-probability sampling where this sampling technique provides opportunities or opportunities that are not equal for each member of the population to be selected as a sample.

\section{Measurement}

The data in this study are primary data obtained from respondents who work at PT Arga Bangun Bangsa through surveys with questionnaires and interviews and is supported by secondary data obtained from relevant agencies or sources. All variables were measured using a five-point Likert scale "strongly disagree $=1$ and strongly agree $=5$ ".
Innovative Work Behavior, the measurement of IWB using a measurement constructed by De Jong \& Hartog (2010). There are four dimensions, namely opportunity exploration, idea generation, championing, and implementation, with 10 items. Sample items used to measure the IWB construct include such as "I search out new working methods, techniques or instruments" "I attempt to convince people to support an innovative idea" "I wonder how things can be improved", the generated value of the coefficient of Cronbach's $\alpha$ is 0.90 .

Measurement of Transformational Leadership in this study uses a questionnaire used by Bass \& Avolio, 2003, which covers the four dimensions of TL: (1) idealized influence, (2) inspirational motivation, (3) intellectual stimulation, and (4) individualized consideration. With a total of 12 items. Sample items are "My supervisor communicates high hopes / vision". Cronbach's alpha of the summative scale was 0.93 .

Individual entrepreneurial orientation. Adapted from measures by Langkamp Bolton and Lane (2012), ten-item individual entrepreneurial orientation scale encompasses the three dimensions: proactiveness consists of two items, innovativeness with three items, and risk-taking with three items. Sample items are "I like to act quickly to anticipate problems, needs, and / or changes". With a Cronbach alpha value of 0.82

Knowledge sharing. KS was measured with seven items developed by Hooff and Weenen (2004). KS is tested as mediating a variable between TL and IWB. The moderating role of $\mathrm{KS}$ on the relationship between IEO and IWB is also tested in this study. The sample item was "I shared the information I had with coworkers, when they asked me to do it". These items generated coefficient of Cronbach's $\alpha$ was 0.80 .

\section{$>$ Data Analysis Method}

This study uses data analysis techniques using SmartPLS software version 3.2.7 which is run on computer media. PLS (Partial Least Square) is an analysis of structural equations (Structural Equation Modeling) or abbreviated SEM based on variants that can simultaneously conduct measurement model testing as well as structural model testing.

\section{RESULTS AND DISCUSSION}

\section{$>$ Descriptive Analysis of Respondents}

Based on the results of data processing shows that of 115 respondents there were 56 respondents or $48.70 \%$ were male. And 59 respondents or $51.30 \%$ were female. Respondents who have the mostly number of ages are 25 39 years (Generation $\mathrm{Y}$ or Millennial) as many as 83 respondents or $72.17 \%$ and the lowest number of ages is > 55 years which is as much as 1 respondent or as much as $0.87 \%$. of the 115 respondents, the number of respondents who had the most tenure was 1-5 years with 64 respondents or $55.65 \%$ and the least number of years of work was $<1$ year with 14 respondents or $12.17 \%$. 


\section{Descriptive Analysis Variable}

The transformational leadership variable has an average score of 3.04. This shows that most respondents gave good responses because they were in the range of agree and strongly agree. Furthermore, it can be seen that the dimension of transformational leadership which has the highest mean value is found in the ideal influence dimension with a mean value of 3.10 with a standard deviation of 0.49 .

Individual entrepreneurial orientation variable has an average score of 3.02. This shows that most respondents gave good responses because they were in the range of agree and strongly agree. Furthermore, it can be seen that the dimension of individual entrepreneurial orientation that has the highest mean value is in the proactive dimension with a mean value of 3.19 with a standard deviation of 0.42 .

The knowledge sharing variable has an average score of 3.05. This shows that most respondents gave good responses because they were in the range of agree and strongly agree. Furthermore, it can be seen that the dimension of knowledge sharing that has the highest mean value is in the dimension of knowledge collecting with a mean value of 3.10 with a standard deviation of 0.41 .

The innovative work behavior variable has an average score of 3.09. This shows that most respondents gave good responses because they were in the range of agree and strongly agree. Furthermore, it can be seen that the dimension of innovative work behavior that has the highest mean value is in the dimension of issuing ideas with a mean value of 3.14 with a standard deviation of 0.48 .

\section{Validity and Reliability}

Evaluation of convergent validity from the examination of Average Variance Extracted (AVE) can be seen from the value of AVE based on the results of data processing with SmartPLS version 3.0.

\begin{tabular}{|c|c|}
\hline Variable & $\begin{array}{c}\text { Average Variance } \\
\text { Extracted Value (AVE) }\end{array}$ \\
\hline Transformasinal Leadership & 0.618 \\
\hline $\begin{array}{c}\text { Individual Entrepreneurial } \\
\text { Orientation }\end{array}$ & 0.519 \\
\hline Knowledge Sharing & 0.558 \\
\hline Innovative Work Behavior & 0.560 \\
\hline
\end{tabular}

Table 1: - Average Variance Extracted (AVE)

All variables have AVE values > 0.5, each of 0.619 for transformational leadership, 0.521 for individual entrepreneurial orientation, 0.561 for sharing knowledge, and 0.560 for innovative work behavior.
Evaluation of convergent validity from internal consistency reliability checks can be seen from the value of Cronbach's Coefficient Alpha and Composite Reliability (CR)

\begin{tabular}{|c|c|c|}
\hline Variable & $\begin{array}{c}\text { Cronbach's } \\
\text { Coefficient } \\
\text { Alpha }\end{array}$ & $\begin{array}{c}\text { Composite } \\
\text { Reability (CR) }\end{array}$ \\
\hline $\begin{array}{c}\text { Transformasinal } \\
\text { Leadership }\end{array}$ & 0.931 & 0.942 \\
\hline $\begin{array}{c}\text { Individual } \\
\text { Entrepreneurial } \\
\text { Orientation }\end{array}$ & 0.825 & 0.865 \\
\hline $\begin{array}{c}\text { Knowledge sharing } \\
\text { Innovative Work } \\
\text { Behavior }\end{array}$ & .804 & .853 \\
\hline
\end{tabular}

Table 2: -Composite Reability (CR)

Cronbach's Coefficient Alpha for transformational leadership variables, individual entrepreneurial orientation, knowledge sharing, and innovative work behavior is more than 0.6 or even close to 1 and the Composite reliability (CR) value is more than 0.7. In table 4.13 it is known that the Cronbach's Coefficient Alpha value and the Composite reliability value for all research variables are more than 0.80 or even close to 1 . This value has already exceeded the standards are respectively $>0.6$ and $>0.7$, so that all variables in the study are declared reliable.

\begin{tabular}{|c|c|c|c|}
\hline & $\begin{array}{c}\text { Original } \\
\text { Sample } \\
(0)\end{array}$ & $\begin{array}{c}\text { T Statistics } \\
(\mid \text { O / STDEV } \mid)\end{array}$ & $\begin{array}{c}\mathbf{P} \\
\text { Values }\end{array}$ \\
\hline $\mathrm{TL} \rightarrow \mathrm{KS}$ & 0.243 & 2,073 & 0.039 \\
\hline $\mathrm{IEO} \rightarrow \mathrm{KS}$ & 0.444 & 3,959 & 0,000 \\
\hline $\mathrm{TL} \rightarrow \mathrm{IWB}$ & 0.456 & 3,680 & 0,000 \\
\hline IEO $\rightarrow$ IWB & 0.308 & 2,074 & 0.039 \\
\hline $\mathrm{KS} \rightarrow \mathrm{IWB}$ & 0.188 & 1,829 & 0.068 \\
\hline
\end{tabular}

Table 3: -Path Coefficient (CR).

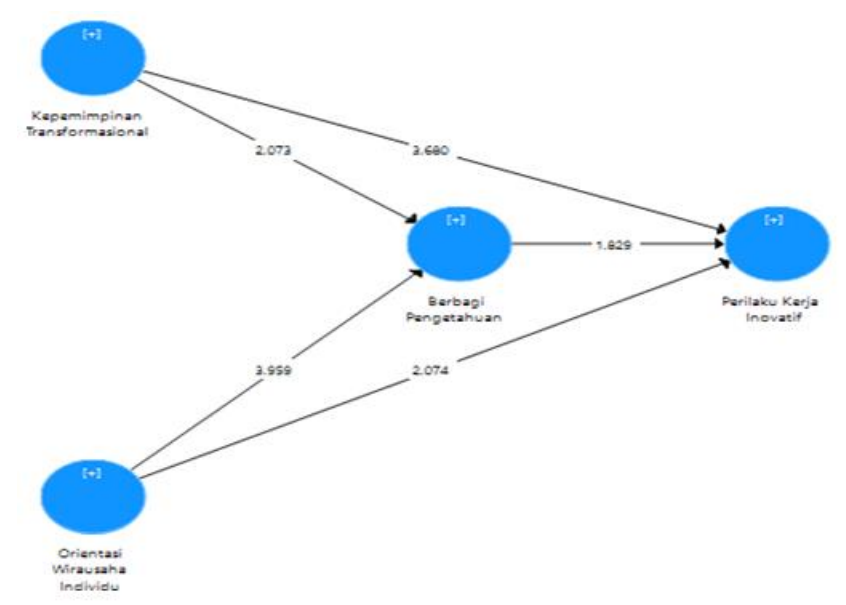

Fig 2:- Inner Model (Original Sample) 


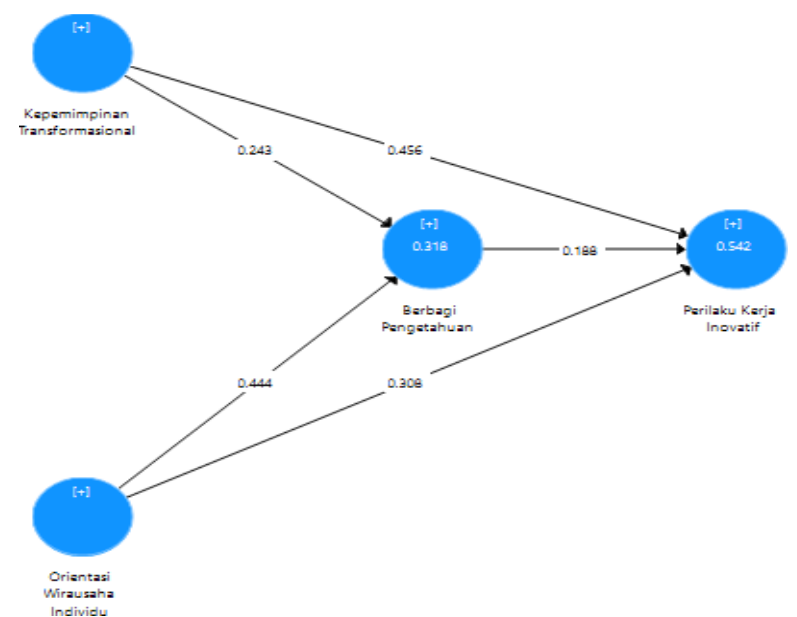

Fig 3:- Inner Model (T Statistics (O / STDEV))

The simultaneous effect of transformational leadership variables and individual entrepreneurial orientation on knowledge sharing can be done by calculating $\mathrm{f} /$ statistic using the formula as below.

$\mathrm{R}^{2}=0.318$ (Knowledge Sharing)

$\mathrm{F}$ value $1=\quad(k-1) \quad 1-R /(n-k) 0.318$

$\mathrm{F}$ value $1=\quad(4-1) \quad 1-0.318 /(115-4)$

F value $1=0.106 / 0.0061$

$\mathrm{F}$ value $1=17.37$

So that the amount of $F$ value of Knowledge Sharing Variables is 17.37 .

Furthermore, the simultaneous influence of transformational leadership variables, individual entrepreneurial orientation, and knowledge sharing on innovative work behaviors can be done by calculating $\mathrm{f} /$ value using the formula as below.

$\mathrm{R}^{2}=0.542$ (Innovative Work Behavior)

$\mathrm{F}$ value $2=\quad(k-1) 1-R /(n-k) 0.542$

$\mathrm{F}$ value $2=\quad(4-1) 1-0,542 /(115-4)$

F value $2=0.180 / 0.0041$

$F$ value $2=43.90$

So that the large $\mathrm{F}$ value is the innovative work behavior variable that is 43.90

The purpose of testing the Goodness of Fit Index $(\mathrm{GoF})$ is to validate the combined performance of the measurement model (outer model) and the structural model (inner model) obtained through calculations as follows:

$\mathrm{GoF}=\sqrt{ } A V E x R 2$

$\mathrm{GoF}=\sqrt{50,56 x} 0.086$

$\mathrm{GoF}=\sqrt{ } 0,048$

$\mathrm{GoF}=0.219$

$\mathrm{AVE}=(0.618+0.519+0.558+0.560) / 4=0.56$

$\mathrm{R}$ square $=(0.318 \times 0.542) / 2=0.086$
The results of the Goodness of Fit Index (GoF) calculation showed a value of 0.219. According to Tenenhau (2004), a small GoF value $=0.1$, a medium GoF $=0.25$, and a large $\mathrm{GoF}=0.36$. Based on these results it can be concluded that the combined performance of the measurement model (outer model) and structural model (inner model) as a whole is quite good because the Goodness of Fit Index (GoF) value is 0.21.

The purpose of testing predictive relevance $(\mathrm{Q} 2)$ is to validate the model. The results of the $\mathrm{Q} 2$ calculation are as follows:

$\mathrm{Q} 2=1-(1-\mathrm{R} 12)(1-\mathrm{R} 22)$

$\mathrm{Q} 2=1-(1-0.318)(1-0.542)$

$\mathrm{Q} 2=1--(0.682)(0.458)$

$\mathrm{Q} 2=1-0.312$

$\mathrm{Q} 2=0.688$

Based on the predictive relevance (Q2) calculation above, the value is 0.688 . In this research model, endogenous latent variables have predictive relevance (Q2) values greater than 0 (zero) so that exogenous latent variables as explanatory variables are able to predict their endogenous variables, namely innovative work behavior variables or in other words prove that this model is considered to have predictive good relevance.

\begin{tabular}{|c|c|c|c|}
\hline & $\begin{array}{c}\text { T Statistics } \\
(\mid \text { O/STDEV })\end{array}$ & $\begin{array}{c}\text { T } \\
\text { Table }\end{array}$ & $\begin{array}{c}\text { P. } \\
\text { Values }\end{array}$ \\
\hline $\mathrm{TL} \rightarrow$ IWB & 3,680 & 1,982 & 0,000 \\
\hline $\mathrm{IEO} \rightarrow \mathrm{IWB}$ & 2,074 & 1,982 & 0.039 \\
\hline $\mathrm{TL} \rightarrow \mathrm{KS}$ & 2,073 & 1,982 & 0.039 \\
\hline $\mathrm{IEO} \rightarrow \mathrm{KS}$ & 3,959 & 1,982 & 0,000 \\
\hline $\mathrm{KS} \rightarrow \mathrm{IWB}$ & 1,829 & 1,982 & 0.068 \\
\hline
\end{tabular}

Table 4: - Effect of Independent Variables to Dependent Variables

Hypothesis 1 - Transformational leadership has a significant effect on innovative work behavior. Obtained a path coefficient of 0.456 and $t$ value (3.680)> t table (1.982) with $\mathrm{p}$ of 0.000 , thus $\mathrm{H} 1$ is accepted $(\mathrm{p}<0.05)$ and $\mathrm{HO}$ is rejected, so that transformational leadership has a positive effect on innovative work behavior. Hypothesis 2 Individual entrepreneurial orientation has a significant effect on innovative work behavior. Obtained a path coefficient of 0.308 and $t$ value (2.074)> t Table (1.982) with $\mathrm{p}$ of 0.039 , thus $\mathrm{H} 2$ is accepted $(\mathrm{p}<0.05)$ and $\mathrm{H} 0$ is rejected, so that individual entrepreneurial orientation has a positive effect on innovative work behavior.

Hypothesis 3 - Transformational leadership has a significant effect on knowledge sharing. Obtained a path coefficient of 0.243 and $t$ value (2.073)> t Table (1.982) with $\mathrm{p}$ of 0.039 , thus $\mathrm{H} 3$ is accepted $(\mathrm{p}<0.05)$ and $\mathrm{H} 0$ is rejected, so that transformational leadership has a positive effect on knowledge sharing. Hypothesis 4 - Individual entrepreneurial orientation has a significant effect on knowledge sharing. Obtained a path coefficient of 0.444 
and $t$ value (3.959)> t Table (1.982) with $\mathrm{p}$ of 0.000 , thus $\mathrm{H} 4$ is accepted $(\mathrm{p}<0.05)$ and $\mathrm{H} 0$ is rejected, so that the orientation of individual entrepreneurs has a positive effect on knowledge sharing.

Hypothesis 5 - Sharing knowledge has no significant effect on innovative work behavior. Obtained a path coefficient of 0.188 and $t$ value $(1.829)<t$ Table $(1.982)$ with $\mathrm{p}$ of 0.068 , thus $\mathrm{H} 5$ is rejected (p > 0.05) and $\mathrm{H} 0$ is accepted, so knowledge sharing has no effect on individual work behavior. Hypothesis 6 and Hypothesis 7 - As for testing hypotheses with a mediating effect on $\mathrm{H} 6$ and $\mathrm{H} 7$, indirect relationships are said to be able to mediate if indirect relationships > direct relationships, and do not mediate if indirect relationships <direct relationships. Hypothesis 6 - Direct and indirect comparisons show that the influence of transformational leadership on innovative work behavior is 0.456 which is greater than the influence of transformational leadership on innovative work behavior through knowledge sharing of 0.045 (see table 5) at PT Argaangun Bangsa.

Hypothesis 7 - direct and indirect comparison shows that the effect of individual entrepreneurial orientation on innovative work behavior is 0.308 (see table 4) which is greater than the effect of individual entrepreneurial orientation on innovative work behavior through 0.083 knowledge sharing (see table 5) at PT Arga Bangun Bangsa. This shows that $\mathrm{H} 7$ is rejected, that sharing knowledge does not mediate the effect between individual entrepreneurial orientation on innovative work behavior.

\begin{tabular}{|c|c|c|c|c|}
\hline & $\begin{array}{c}\text { Sampel } \\
(\mathbf{O})\end{array}$ & $\begin{array}{c}\text { T Statistik } \\
\text { (O/STDEV) }\end{array}$ & $\begin{array}{c}\mathbf{T} \\
\text { Tabel } \\
\end{array}$ & $\begin{array}{c}\mathbf{P} \\
\text { Values }\end{array}$ \\
\hline $\begin{array}{c}\mathrm{TL} \rightarrow \mathrm{KS} \rightarrow \\
\mathrm{IWB}\end{array}$ & $\begin{array}{c}0,243 \times \\
0,188= \\
0,045\end{array}$ & 1,218 & 1,982 & 0,224 \\
\hline $\begin{array}{c}\mathrm{IEO} \rightarrow \mathrm{KS} \\
\rightarrow \mathrm{IWB}\end{array}$ & $\begin{array}{c}0,444 \times \\
0,188= \\
0,083\end{array}$ & 1,515 & 1,982 & 0,130 \\
\hline
\end{tabular}

Table 5:- Indirect Effect Independent Variables on Dependent Variables

\section{$>$ Correlation Analysis between Dimensions}

The leadership variable on the knowledge sharing variable, the highest correlation dimension is the individual consideration dimension that is equal to 0.251 . The individual entrepreneurial orientation variable towards the knowledge sharing variable, the highest correlation dimension is the proactive dimension that is equal to 0.425 .

The transformational leadership variable on the innovative work behavior variable, the highest correlation dimension is the inspiration motivation dimension that is 0.302. The individual entrepreneurship orientation variable towards the innovative work behavior variable, the highest correlation dimension is innovative, that is 0.292 . The knowledge sharing variable on innovative work behavior variables, the highest correlation dimension is knowledge collecting that is equal to 0.317 .

\section{DISCUSSION}

\section{$>$ Effects of Transformational Leadership on Innovative Work Behavior}

Based on the hypothesis test in this study indicate that transformational leadership has a positive and significant effect on innovative work behavior on the employees of PT Arga Bangun Bangsa. The results of hypothesis testing in this study can be interpreted that increasing transformational leadership will also improve the innovative work behavior of PT Arga Bangun Bangsa employees. The results of the hypothesis in this study are supported by research conducted by Kresnandito, (2012) which states that transformational leadership has a significant effect on innovative work behavior.

\section{- Effect of Individual Entrepreneurial Orientation on Innovative Work Behavior}

Based on the hypothesis test, the results in this study indicate that individual entrepreneurial orientation significantly influences the innovative work behavior of PT Arga Bangun Bangsa employees. The results of hypothesis testing in this study can be interpreted that by increasing individual entrepreneurial orientation will also improve the innovative work behavior of PT Arga Bangun Bangsa employees. The results of the hypothesis in this study are supported by research conducted by Kör (2016) suggested that entrepreneurship orientation had a significant influence on employees' innovative work behavior. According to Kör, individuals are more likely to engage in innovative work behavior when the company has a high level of entrepreneurial orientation. When organizations have a strong entrepreneurial orientation climate, the process or practice in creating an environment of innovation, proactivity, and risk-taking behavior that can also stimulate individual self-leadership skills.

\section{Effects of Transformational Leadership on Knowledge Sharing}

Based on hypothesis testing in this study, the results of hypothesis testing in this study indicate that transformational leadership has a significant effect on knowledge sharing among PT Arga Bangun Bangsa employees. The results of hypothesis testing in this study can be interpreted that by increasing transformational leadership will also increase the knowledge sharing of employees of PT Arga Bangun Bangsa. The results of the hypothesis in this study are supported by research conducted by Helmi and Arisudana (2009) finding that transformational leadership has an influence on knowledge sharing.

\section{- Effect of Individual Entrepreneurial Orientation on Knowledge Sharing}

Based on the hypothesis test in this study, the results of hypothesis testing in this study indicate that individual entrepreneurial orientation significantly influences knowledge sharing among PT Arga Bangun Bangsa employees. The results of hypothesis testing in this study can be interpreted that by increasing individual entrepreneurial orientation will also increase the knowledge 
sharing of employees of PT Arga Bangun Bangsa. The results of the hypothesis in this study are supported by research conducted by Tuan (2015) showing that individual entrepreneurial orientation has a significant influence on knowledge sharing.

\section{$>$ Effects of Knowledge Sharing on Innovative Work Behavior}

The results of hypothesis testing in this study indicate that sharing of knowledge does not have a significant effect on innovative work behavior on the employees of PT Arga Bangun Bangsa. The results of hypothesis testing in this study can be interpreted that by increasing individual entrepreneurial orientation will also increase the knowledge sharing of employees of PT Arga Bangun Bangsa. Most of PT Arga Bangun Bangsa's employees said that the innovation they did was not through knowledge sharing activities, but rather because of their inclination towards creativity and experimentation through the introduction of new products and services and technological leadership through research and development in new processes.

\section{$>$ Effects of Transformational Leadership on Innovative Work Behavior through Knowledge Sharing \\ The path coefficient value of the direct influence of transformational leadership on innovative work behavior greater than the value of the path coefficient of the indirect effect of transformational leadership on innovative work behavior, then the transformational leadership on innovative work behavior is not mediated by the knowledge sharing variable.}

Based on the above theoretical studies, it can be indicated that sharing knowledge does not mediate transformational leadership to innovative work behavior. In this study, it is known that the direct effect of transformational leadership on innovative work behavior is greater when compared to its indirect effect, relevant to conditions on the ground with the role of directors who have transformational leadership characteristics able to influence their subordinates to work independently, willing to express their ideas, and make an improvement for the company PT Arga Bangun Bangsa.

\section{The Effect of Individual Entrepreneurial Orientation on Innovative Work Behavior through Knowledge Sharing \\ The path coefficient value of the direct effect of individual entrepreneurial orientation on innovative work behavior greater than the value of the path coefficient of indirect effect of individual entrepreneurial orientation on innovative work behavior, then the orientation of individual entrepreneurship towards innovative work behavior is not mediated by the knowledge sharing variable.}

Based on the above theoretical studies, it can be indicated that sharing knowledge does not mediate the orientation of individual entrepreneurs towards innovative work behavior. In this study it is known that the direct effect of individual entrepreneurial orientation on innovative work behavior is greater when compared to its indirect effect, relevant to conditions on the ground because individual employees of PT Arga Bangun Bangsa who are able to run improvement or even make an innovation are those who dare to face work risks and the tendency of individuals to experiment with a new development and of course with the full support of superiors.

\section{CONCLUSION}

Based on the research results simultaneously transformational leadership variables, individual entrepreneurial orientation, and knowledge sharing significantly influence individual work behavior variables. As for the discussions in the previous chapters, several conclusions can be made as follows: Transformational leadership has a significant positive effect on innovative work behavior, with the most inspiring motivational dimensions being influential. Individual entrepreneurial orientation has a significant positive effect on innovative work behavior, with the most influential innovative dimension. Transformational leadership has a significant positive effect on knowledge sharing, with the individual dimension of consideration most influential. Individual entrepreneurial orientation has a significant positive effect on knowledge sharing, with the proactive dimension being the most powerful. Knowledge sharing has no significant effect on innovative work behavior. Sharing knowledge does not mediate transformational leadership towards innovative work behavior. Sharing knowledge does not mediate individual entrepreneurial orientation towards innovative work behavior.

\section{SUGGESTION}

Based on the results of the analysis of the discussion and some conclusions above, the suggestions that can be given to supplement the results of this study are as follows:

\section{For Companies}

The results the analysis shows that transformational leadership influences employee behavior to innovate at PT Arga Bangun Bangsa. On the motivational dimension of inspiration significantly influences innovative work behavior on the dimension of idea generation. The company has begun to prepare the next leader who is able to demonstrate commitment to the goals of the organization, and is able to inspire enthusiasm in the organization through growing the enthusiasm and optimism of his subordinates, especially in terms of developing the problem solving abilities of his subordinates so that employees are able to find innovative ideas that are expected to have an impact on the sustainability of the organization .

Individual entrepreneurial orientation significantly influences innovative work behavior and correlations between dimensions show significant on the innovative dimensions of the dimension of idea generation, the companies need to improve their creativity in order to improve the ability to solve problems faced by each employee. The companies can provide training in problem solving and decision making or also provide training that 
can hone the ability of creative thinking of employees, such as involving employees in certain cases and inviting them to provide input to solve these problems. Transformational leadership influences knowledge sharing and correlation results between dimensions show that the dimensions of individual considerations significantly influence the dimension of knowledge collecting. The company also needs to focus on forming leaders who are willing to listen attentively to their subordinates and ask top management to create knowledge sharing programs on a weekly or monthly basis.

Results the analysis shows that the orientation of the individual entrepreneur influences the sharing of knowledge and the correlation between dimensions shows that the proactive dimension significantly influences the knowledge collecting. It is expected that the company is able to build a proactive culture to its employees in sharing knowledge. Can be done with programs that can open borders between work units so that they are more flexible in sharing their knowledge. Furthermore, knowledge sharing has no significant effect on innovative work behavior and the correlation between the dimensions of the greatest on the dimensions of knowledge collecting on the knowledge sharing variable to the dimension of idea generation on innovative work behavior variables. Although it does not have a significant influence, in increasing employee work innovation, companies also need to consider this because the relationship between dimensions is quite large, meaning that in idea generation to innovate, employees still need the process of collecting knowledge or sharing knowledge between employees or between work units. What can be done by the company or management can facilitate employees to create a sharing is caring program.

Knowledge sharing does not mediate the effect of transformational leadership on innovative work behavior. In forming employees who can innovate, it takes leaders who focus on the company's vision, mission, and values, in this case transformational leaders. The way companies can do to prepare transformational leaders who can support employee innovation can be done without the process of sharing knowledge. In other words, it is expected that employees at PT Arga Bangun Bangsa need a leader who supports the innovative work behavior of their subordinates. Moreover, sharing knowledge does not mediate the effect between individual entrepreneurial orientation on innovative work behavior. The characteristics of the employees of PT Arga Bangun Bangsa already have the value of innovation in themselves, just how the company can maintain these values so that employees remain motivated to continue to be creative in solving a problem, and provide new breakthroughs in the work process.

\section{$>$ For Further Research}

Expectations from the authors for further research, so that they can dig deeper related variables that affect innovative work behavior, for example can use the variables of individual attitudes, communication, interaction between groups, and so on. The significant effect of knowledge sharing as a mediator on innovative work behavior was not found in this study. It is hoped that what is found in this research will be developed further to open up the possibility of other influences besides for example organizational culture, organizational climate, and aside from knowledge sharing variables on innovative work behavior variables.

Based on valid results that knowledge sharing as an independent variable does not mediate transformational leadership and individual entrepreneurial orientation towards innovative work behavior and it is recommended that knowledge sharing be added to the dependent variable and not to the variable mediate more innovative work behavior if done in the same research object. And if you want to continue to use as a variable of knowledge sharing as mediation, you can use another theory besides the Hoff $\&$ Weenan theory and with the object of research that is different from the object of research in this study.

\section{REFERENCES}

[1]. De Jong, J., \& Den Hartog, D. (2010). Measuring innovative work behaviour. Creativity and innovation management, 19(1), 23-36.

[2]. Setyowati, S., \& Etikariena, A. (2019). Peran Gaya Pemecahan Masalah dalam Hubungan Kepemimpinan Transformasional dengan Perilaku Kerja Inovatif. Jurnal Diversita, 5(2), 115-125.

[3]. Paracha, M. U., Qamar, A., Mirza, A., Hassan, I. U., \& Waqas, H. (2012). Impact of leadership style (transformational \& transactional leadership) on employee performance \& mediating role of job satisfaction. Study of private school (educator) in Pakistan. Global Journal of Management and Business Research, 12(4), 55-64.

[4]. Paulus, Dialson, (2019). The Influence of Work Morale and Competence on Work Motivation and Its Implementation Against Work Productivity of PT. Sinar Metrindo Perkasa. Jakarta: Mercu Buana University

[5]. Yukl, Gary. (2010). Kepemimpinan Dalam Organisasi. Edisi Kelima. Indeks. Jakarta.

[6]. Saragih, R. (2017). Membangun Usaha Kreatif, Inovatif Dan Bermanfaat Melalui Penerapan Kewirausahaan Sosial. Jurnal Kewirausahaan, 3(2), 26-34.

[7]. Listyawati, I. H. (2017). Pengaruh sikap, norma subyektif dan kontrol keperilakuan terhadap niat berwirausaha pada mahasiswa di Yogyakarta. Jurnal Bisnis, Manajemen, dan Akuntansi, 4(1).

[8]. Langkamp Bolton, D., \& Lane, M. D. (2012). Individual entrepreneurial orientation: Development of a measurement instrument. Education+ Training, 54(2/3), 219-233.

[9]. Islamy, F. J., \& Mubarok, D. A. A. (2019). Pengaruh motivasi, kepercayaan dan komunikasi terhadap implementasi knowledge sharing pada perguruan tinggi negeri di kota Bandung. E-Jurnal STIE INABA, 18(03), 16-30. 
[10]. Jaberi, E. (2016). The effect of knowledge sharing on innovative behavior among employee of Besat hospital in city of Hamedan. International Academic Journal of Accounting and Financial Management, 3(4), 41-47.

[11]. Van den Hooff, B. and Van Weenen, F.D.L. (2004). Knowledge sharing in context: the influence of organizational commitment, communication climate and CMC use on knowledge sharing, Journal of Knowledge Management, Vol. 8 No. 6, pp. 117-30.

[12]. Kresnandito, A. P. (2012). Pengaruh Persepsi Kepemimpinan Transformasional terhadap Perilaku Inovatif Penyiar Radio. Jurnal Psikologi Industri dan Organisasi, 1(02).

[13]. Kör, B. (2016). The mediating effects of selfleadership on perceived entrepreneurial orientation and innovative work behavior in the banking sector. SpringerPlus, 5(1), 1829.

[14]. Helmi, A. F., \& Arisudana, I. (2009). Kepemimpinan transformasional, kepercayaan dan berbagi pengetahuan dalam organisasi. Jurnal Psikologi, 36(2), 95-105.

[15]. Tuan, L. T. (2015). From corporate social responsibility, through entrepreneurial orientation, to knowledge sharing. The Learning Organization. 